\title{
Evaluation of Physicochemical Characteristics of Soils in the Flood Disaster Affected Areas of Isoko Region of Delta State, Nigeria.
}

\author{
Osakwe, S. A. \\ Department of Chemistry, Delta State University, Abraka, Delta State, Nigeria.
}

Abstract: The physicochemical properties of soils from natural flood disaster affected areas of Isoko Region of Delta State, Nigeria, were investigated. The results indicated that there was an overall reduction in soil $\mathrm{pH}(5.425 \pm 0.313)$, phosphorus $\left(7.47 \pm 6.34 \mathrm{mgkg}^{-1}\right)$, and nitrate $\left(0.34 \pm 0.07 \mathrm{mgkg}^{-1}\right)$ contents as well as exchangeable calcium $1.97 \pm 0.31 \mathrm{mgkg}^{-1}$ potassium $\left(0.09 \pm 0.01 \mathrm{mgkg}^{-1}\right)$, and effective cation exchange capacity $\left(5.076 \pm 1.532\left(\mathrm{cmolkg}^{-1}\right)\right)$ and related parameters with 3.87 $\pm 0.21,77.57 \pm 5.83$ and $7.99 \pm 2.72$ for Base Exchange Capacity, Base Saturation and Soil Buffering capacity respectively. There was however increase in the values of exchangeable magnesium (1.50 $\left.\pm 0.25 \mathrm{mg} \mathrm{kg}^{-1}\right)$, exchangeable sodium $\left(0.28 \pm 0.004 \mathrm{mgkg}^{-1}\right)$ and also exchangeable acidity with the values $0.43+0.08$ and $0.42 \pm 1.02 \mathrm{mgkg}^{-1}$ for Hydrogen and Aluminum respectively. There was no appreciable change in the values of Total Organic Carbon $(0.40 \pm 0.096 \%)$, Total Nitrogen $(0.025 \pm 0.035 \%)$ and Sulphate $\left(0.10 \pm 0.02 \mathrm{mgkg}^{-1}\right)$. The overall results indicate that the flood increased soil acidity and decreased the ability of the soils to adsorb metals, but did not have appreciable effect on the biodegradable and compostable materials. Government should be proactive and devise measures to prevent further flood disaster in the country.

Keywords: Flood disaster, soils, physicochemical characteristics, Pollution, Isoko Region.

\section{Introduction}

Flooding is the most common of all environmental hazards and it regularly claims over 20,000 lives per year and adversely affects around 75million people worldwide, causing about one third of all deaths, one third of all injuries and one third of all damages, from natural disasters. [1] In Nigeria, floods are common features during the rainy season (May - October) occurring naturally on the flood plains when water in the rivers and their tributaries overflow their banks. These floods are usually restricted to the river flood plains which are low lying coastal areas of the country.

The 2012 Nigerian flood disaster which took effect from August to October 2012 has been described as the worst and unprecedented in the history of Nigeria. The flood was caused by the release of waters from Ladgo dam in Cameroon into River Benue flood plain coupled with the effect of global warming [2]. Rivers Niger and Benue burst their banks engulfing lakes, ponds, farmlands, and settlements within their flood plains and then submerged hundreds of kilometers of urban and rural lands. Some of the areas mostly affected by this flood disaster include some States in Central Nigeria, Benue, Kogi, Niger, Nasarawa and Kwara, and some others in the south which include, Anambra, Delta, Bayelsa, Rivers, Cross Rivers, Akwa-Ibom, Edo and others. During the flooding, lands, buildings, were submerged rendering many people homeless, properties were destroyed and lives were lost.

After the flood had receded, the evaluation of damages typically was centered on homes, business, roads, utility services, lives lost and others, forgetting that flood water also can have pronounced influence on soil fertility and its physical and chemical properties as well as creating potentially serious environmental issues. During the flood some of the things destroyed transported and finally deposited on the soil especially those from contaminated sites may contain toxic elements and these will obviously affect both the physical and chemical properties of the soil.

Physicochemical properties of soil are complex, often non-linearly related and spatially and temporally dynamic [3]. Although there have been many studies on soil physicochemical properties of soil $[4,5,6]$, there has not been any information on the physical and chemical properties of soils affected by the recent Nigerian flood disaster. The objective of this study therefore was to determine the physicochemical properties of the soil samples from the flood affected soils of the Isoko region of Delta State, Nigeria, in order to assess the impact of the flood on the soil quality. 


\section{Materials and Methods}

\section{Description of the Study Area}

The study area lies between Latitude $5^{0} 22^{1} 55.55^{11}\left(5.381^{0}\right)$ North and Longitude $6^{0} 12^{1} 51^{11}\left(6.2142^{0}\right)$ East. It has a tropical climate which is marked by two distinct seasons, the dry and rainy seasons which occur between November and March and between April and October respectively. The average annual rainfall is about $270 \mathrm{~cm}$. The rainfall is heaviest in the months of July and August. The area has a high temperature ranging between 28 and $45^{\circ} \mathrm{C}$ depending on the season. The vegetation is mangrove swamp/forest and the major economic trees are palm and rubber with few others like Iroko, Obeche, Abora, Rafia and Mahogany. The occupations of the people are farming, fishing, trading and teaching.

\section{Sample Collection}

Soil samples were collected from seven different flood affected towns in Isoko Area of Delta State, Nigeria, using soil auger. In each town, samples were collected from three different locations at depths $0-15 \mathrm{~cm}, 15-$ $30 \mathrm{~cm}$ and $30-45 \mathrm{~cm}$, representing top, sub and bottom soils respectively. The auger borings from each depth from each town were bulked and representative samples were finally taken after series of coning and quartering [7]. Soil samples were also collected from another town in the same area which was not affected by flood, as control.

\section{Sample Preparation}

The soil samples were air-dried for a period of one week in a clean well - ventilated laboratory [8], homogenized by grinding, passed through a $2 \mathrm{~mm}$ (10mesh) stainless sieve and stored in labeled plastic cans ready for analysis.

\section{Sample Analysis}

Soil $\mathrm{pH}$ was measured in a soil-water ratio of 1:2.5 [9] Total Organic Carbon (TOC) was determined by the method described by Nelson and Sommers, [10]. Total Nitrogen was analyzed using Micro-Kjeldahl method. Available phosphorus was determined by the method of Bray and Kurtz [11], while particle size to separate sand, silt and clay was achieved using the method of Bouyocous [12], Exchangeable cations and cation exchange capacity were determined by Schollenberger and Simons, [13] method while exchangeable acidity $\left(\mathrm{H}^{+}, \mathrm{Al}^{3+}\right)$ was determined by the method of Jackson and Burton [14]. Sulphate and nitrate were determined calorimetrically [15]. Electrical conductivity was measured by the method of Chopra and Kanzar [16]. All reagents used in this study were of pure analytical grade and all the analyses were done in duplicate.

\section{Results and Discussion}

Table 1 presents some physicochemical characteristics of the soils from all the sites.

Table 1: Physicochemical Properties of the Soil Samples in all sites

\begin{tabular}{|c|c|c|c|c|c|c|c|c|c|c|}
\hline $\begin{array}{l}\text { Sampl } \\
\text { e Site }\end{array}$ & $\begin{array}{c}\text { Dept } \\
\text { h } \\
\text { Cm }\end{array}$ & pH & TOC (\%) & $\begin{array}{l}\text { T.N. } \\
(\%)\end{array}$ & $\begin{array}{c}\mathbf{P} \\
\text { mgkg }^{-1}\end{array}$ & $\begin{array}{c}\mathrm{N0}_{3}^{-} \\
\text {mgkg }\end{array}$ & $\begin{array}{c}\mathrm{SO}_{4}{ }^{2-} \\
\mathrm{mgkg}^{-1}\end{array}$ & $\%$ Clay & \% Silt & $\begin{array}{c}\% \\
\text { Sand }\end{array}$ \\
\hline \multirow[t]{3}{*}{ Site A } & $0-15$ & 5.50 & 0.96 & 0.071 & 26.54 & 0.08 & 0.221 & 7.1 & 3.9 & 89.0 \\
\hline & $15-30$ & 5.20 & 0.51 & 0.034 & 12.84 & 0.70 & 0.21 & 9.0 & 2.5 & 88.5 \\
\hline & $30-45$ & 5.10 & 0.38 & 0.019 & 3.48 & 0.50 & 0.14 & 1.1 & 1.9 & 79.0 \\
\hline \multirow[t]{3}{*}{ Site B } & $0-15$ & 5.00 & 0.19 & 0.008 & 1.21 & 0.34 & 0.02 & 18.6 & 1.4 & 80.0 \\
\hline & $15-30$ & 4.90 & 0.13 & 0.005 & 0.62 & 0.42 & 0.10 & 19.6 & 1.4 & 79.0 \\
\hline & $30-45$ & 4.80 & 0.06 & 0.003 & 0.44 & 0.47 & 0.14 & 20.6 & 0.9 & 78.5 \\
\hline \multirow[t]{3}{*}{ Site C } & $0-15$ & 5.50 & 0.22 & 0.014 & 3.09 & 0.04 & 0.07 & 6.0 & 1.0 & 93.0 \\
\hline & $15-30$ & 5.40 & 0.16 & 0.006 & 1.78 & 0.25 & 0.05 & 6.1 & 0.9 & 93.0 \\
\hline & $30-45$ & 5.10 & 0.10 & 0.004 & 1.68 & 0.07 & 0.04 & 6.9 & 0.5 & 92.6 \\
\hline \multirow[t]{3}{*}{ Site D } & $0-15$ & 5.80 & 0.48 & 0.023 & 23.28 & 0.11 & 0.03 & 3.6 & 1.4 & 95.0 \\
\hline & $15-30$ & 5.70 & 0.32 & 0.019 & 19.48 & 0.25 & 0.04 & 4.6 & 1.4 & 94.0 \\
\hline & $30-45$ & 5.60 & 0.19 & 0.012 & 7.53 & 0.19 & 0.02 & 5.0 & .0 & 94.0 \\
\hline \multirow[t]{3}{*}{ Site E } & $0-15$ & 6.00 & 0.63 & 0.041 & 9.63 & 0.53 & 0.14 & 9.1 & 2.9 & 88.0 \\
\hline & $15-30$ & 5.90 & 0.51 & 0.033 & 5.88 & 0.15 & 0.08 & 9.6 & 2.4 & 88.0 \\
\hline & $30-45$ & 5.70 & 0.22 & 0.008 & 3.53 & 0.89 & 0.07 & 11.6 & 1.4 & 88.0 \\
\hline \multirow[t]{3}{*}{ Site F } & $0-15$ & 5.60 & 1.09 & 0.073 & 15.31 & 0.87 & 0.05 & 8.1 & 3.9 & 88.0 \\
\hline & $15-30$ & 5.50 & 0.76 & 0.051 & 7.75 & 0.52 & 0.19 & 10.6 & 2.4 & 88.0 \\
\hline & $30-45$ & 5.40 & 0.48 & 0.028 & 6.69 & 1.10 & 0.14 & 12.6 & 1.4 & 86.0 \\
\hline \multirow[t]{2}{*}{ Site G } & $0-15$ & 5.60 & 0.48 & 0.029 & 3.63 & 0.12 & 0.09 & 9.6 & 1.4 & 89.0 \\
\hline & $15-30$ & 5.40 & 0.32 & 0.017 & 1.90 & 0.07 & 0.16 & 10.6 & 1.4 & 88.0 \\
\hline
\end{tabular}


Evaluation of Physicochemical Characteristics of Soils in the Flood Disaster Affected Areas of...

\begin{tabular}{|c|c|c|c|c|c|c|c|c|c|c|}
\hline & $30-45$ & 5.10 & 0.19 & 0.008 & 0.86 & 0.02 & 0.20 & 13.6 & 0.4 & 88.0 \\
\hline $\begin{array}{l}\text { Mean } \\
\pm \text { SD }\end{array}$ & & $\begin{array}{c}5.425 \pm 0.31 \\
3\end{array}$ & $\begin{array}{c}0.40 \pm 0.09 \\
6\end{array}$ & $\begin{array}{c}0.025 \pm 0 \\
.035\end{array}$ & $\begin{array}{c}7.47 \pm 6.3 \\
4\end{array}$ & $\begin{array}{c}\mathbf{0 . 3 4 \pm} \\
\mathbf{0 . 0 7}\end{array}$ & $\begin{array}{c}0.10 \pm 0.0 \\
2\end{array}$ & $\begin{array}{c}9.69 \pm 5 . \\
1099\end{array}$ & $\begin{array}{c}2.34 \pm 2 . \\
176\end{array}$ & $\begin{array}{c}87.8 \pm 4 . \\
979\end{array}$ \\
\hline Contro & $0-15$ & 6.50 & 0.59 & 0.034 & 26.91 & 0.67 & 0.14 & 7.6 & 2.4 & 90.0 \\
\hline 1 Site & $15-30$ & 6.40 & 0.47 & 0.029 & 17.33 & 0.92 & 0.15 & 8.6 & 1.4 & 90.0 \\
\hline & $30-45$ & 6.10 & 0.26 & 0.011 & 5.55 & 0.03 & 0.04 & 11.6 & 0.4 & 88.0 \\
\hline $\begin{array}{l}\text { Mean } \\
\pm \mathrm{SD}\end{array}$ & & $6.33 \pm 0.21$ & $0.44 \pm 0.17$ & $\begin{array}{c}0.02 \pm 0 . \\
01\end{array}$ & $\begin{array}{c}16.6 \pm 10 . \\
6\end{array}$ & 0.54 & 0.11 & $\begin{array}{c}9.3 \pm 2.0 \\
8\end{array}$ & $1.4 \pm 1.0$ & $\begin{array}{l}89.3 \pm 2 . \\
99\end{array}$ \\
\hline
\end{tabular}

The $\mathrm{pH}$ of the soils in all the sites ranged from 4.80 to 6.00 with a mean value of $5.43 \pm 0.313$ showing that the soils were moderately acidic. The acidity of the soils in all the sites decreased with depth. This is contrary to the observation in a similar study [5]. The values reported in this study are within the range for optimum plant growth and are in the same range with those reported by some other researchers $[5,17,18]$. The values are however lower than those reported elsewhere $[6,19,20]$. Previous studies have shown that a reduction in $\mathrm{pH}$ may allow the release of toxic metals that would otherwise be adsorbed in the soil or sediment [21]. Consequently the $\mathrm{pH}$ values of these soils indicate a generally high tendency for high availability of the metals thereby increasing the risk of heavy metal plant uptake which may eventually have adverse effect on man through food chain. The $\mathrm{pH}$ values in the control sites were relatively higher than those of the studied sites which suggest that the flood disaster contributed to the acidity of the soils of the affected area. Availability and mobility of trace heavy metals is greatly favoured by reduced soil $\mathrm{pH}(2-6)$ [27] and values obtained in this study fall within this range. Soil $\mathrm{pH}$ is affected by variations in redox potential that periodically occur when the drainage status of soil change from waterlogged to more freely drained and vice versa [23]. $\mathrm{pH}$ greatly affects trace metal complexation either through solubility equilibra or due to complexation by soluble and surface ligands [24]

Total Organic Carbon (TOC) values ranged from (\%) 0.06 to 1.09 with mean value of $0.40 \pm 0.096$. These values are in the same range with the values reported in some studies [5, 25], but comparatively lower than the values reported in some other studies [26, 27]. The amount of total organic carbon decreased sharply with soil depth. The organic carbon content of a soil is the net result of the rates of carbon input (the rate of net photosynthesis) and organic decay [28] and it contributes significantly to acidity through contributions from organic acids and biological activities [29] Flooded soils, due to their low mineralization rate under reduced conditions tend to accumulate fairly substantial organic carbon contents and these have some influence on soil structural behaviour [30]. Organic matter, of which organic carbon is the basis, contains humus, which is responsible for the storage and release of plant nutrients. It is vital to plant life in the maintenance of soil fertility. The total organic carbon content is suggestive of microbial activity leading to release of organic carbon and acidic substances [31]. It can also be attributed to the level of debris deposited on the soil as a result of flood.

Total Nitrogen ranged from (\%) 0.004 to 0.073 with mean value of $0.025 \pm 0.035$. The total Nitrogen values recorded in this study are consistent with the range of values reported elsewhere [32]. Nitrogen chemistry in soils include the constant turnover of nitrogen during organic reactions, oxidation of organic nitrogen to nitrogen and nitrogen (IV) oxide gases (denitrification) or to nitrate (mineralization) and also reduction of nitrogen gas to organic nitrogen (Nitrogen Fixation) [28]. Although apparently many microorganisms are capable of denitrification only a few specialized species, the free-living Azobacter, blue-green algae, some anaerobic bacteria and the symbiotic Rhizobium bacteria in legumes are capable of nitrogen fixation. Nitrogen can be introduced into the soils by natural processes such as lightening and decay of plants and it is essential to plants for formation of living tissues of plants. It is also essential for all living things, as it is an essential component of protein such as DNA, RNA and Vitamins, as well as hormones and enzymes [33]. The low nitrogen level in the soils studied can be attributed to the fact that at weakly acidic $\mathrm{pH}$ the activities of nitrogen converting bacteria are inhibited [34].

The phosphorus contents of the soil samples in all the sites ranged from $\left(\mathrm{mgkg}^{-1}\right) 0.44$ to 26.54 with a mean value of $7.47 \pm 6.34$. The concentrations of phosphorus recorded in this study are almost in the same range with those reported in a similar study [35], but higher than those reported in another study [36] and lower than those documented elsewhere $[4,37]$. Phosphorous is made available to plants through the weathering of rocks and decay of organic matters which might have resulted from dead organisms consumed by the flood. Phosphorous is essential in cell division and energy transformation and also metabolic processes in plants [38]. Soil pollution by phosphorous is not a significant environmental issue except when phosphorous is leached into surrounding water [35]. Soil phosphorous is available in very low amounts to plant since most of the total soil phosphorous is tied up in insoluble compounds and its availability depends on the soil $\mathrm{pH}$ [39]. Deficiency of phosphorous in soil may cause plant leaves to develop purple colouration, stunted plant growth and decay in plant development while excess of it may cause micronutrient deficiency especially Iron and Zinc [40]. 
Evaluation of Physicochemical Characteristics of Soils in the Flood Disaster Affected Areas of...

The nitrate values ranged from $\left(\mathrm{mgkg}^{-1}\right) 0.02$ to 1.10 with mean value of $0.34 \pm 0.07$. The accumulation of nitrate in the environment results from many sources. It is mainly used in inorganic fertilizers. Burning of fossil fuels in power plants and cars, and all internal combustion engines that usually result in the production of nitric acid ammonia as air pollution is another source of nitrate in the environment. Industrial applications of nitrate as an oxidizing agent, in the production of explosives and as purified potassium nitrate for glass making are also potential sources of environmental nitrate. [33]. Natural process of photochemical oxidation of nitrogen to give oxides of nitrogen during lightening and thunderstorm is also another source of nitrate in the environment [41]. Excessive concentration of nitrate in the environment can be hazardous to health, especially for infants and pregnant human [42]. It is a potential human health threat especially to infants causing the condition known as maethemoglobinemia, also called "blue baby syndrome" [43].

Sulphate levels ranged from $\left(\mathrm{mgkg}^{-1}\right) 0.02$ to 0.22 with mean value of $0.10 \pm 0.02$._Similar results have been established [27]. The sulphate concentration in the soil solution is a good indicator of sulphur availability to plants. Sulphur is an essential micronutrient required by plants and animals. Under normal agricultural conditions, the quantity of sulphur released from organic matter and oxidized to the plant-available sulphate form depends to a great extent on the amount and sulphur status of the organic matter present and on satisfactory microbial environment including soil $\mathrm{pH}$, temperature and water status [28]. Deficiency of sulpur in the soil causes initial yellowing of young leaves spreading to whole plant while excess of sulphur in the soil may cause premature dropping of leaves in plants.

The soil particle size distribution had the mean values of (\%) 9.69, 2.34 and 87.84 for clay, silt and sand respectively. Thus sand fraction was the highest, followed by clay and then silt. This is in harmony with reports from some other studies [17, 44, 45] and it is characteristic of the soils of this part of Niger Delta region. This proportion of sand, clay and silt suggested that the soils were coarse in texture. Coarse textured sandy soils usually have a low supply of nutrient and moisture but provide physical support to plant. Fine-textured soils on the other hands, have sufficient water holding capacity, good aeration and often a high supply of nutrients [46]. The amount of clay is really the inorganic colloidal fraction of the soil [28].

Soil texture and acidity affect the adsorption and accumulation of mineral elements by plants and thus play some roles in the vegetation establishment and development of such sites [6, 24, 47].

\section{Exchangeable Ions}

Cation exchange capacity (CEC) is the ability or capacity of a soil colloid to hold cations. Cations include $\mathrm{Na}^{+}, \mathrm{K}^{+}, \mathrm{Ca}^{2+}$ and $\mathrm{Mg}^{2+}$ as well as $\mathrm{H}^{+}$and $\mathrm{Al}^{3+}$. When the exchangeable ions involve basic ions only, it is referred to as Base Exchange Capacity of the soil. Therefore Total Cation Exchange Capacity is the sum of the Base Exchange Capacity and the exchangeable $\mathrm{H}^{+}$and $\mathrm{Al}^{3+}[48]$.

The values of the exchangeable cations $\left(\mathrm{mgkg}^{-1}\right)$ of the soils from all the sites are presented on table 2 .

Table 2: Exchangeable cations of the soils from all the sites $\left(\mathrm{mgkg}^{-1}\right)$

\begin{tabular}{|c|c|c|c|c|c|c|}
\hline Sample Site & $\mathrm{Ca}^{2+}$ & $\mathrm{Mg}^{2+}$ & $\mathrm{Na}^{+}$ & $\mathbf{K}^{+}$ & $\mathbf{H}^{+}$ & $\mathbf{A l}^{3+}$ \\
\hline Site A & $\begin{array}{l}2.08 \\
1.06 \\
1.52\end{array}$ & $\begin{array}{l}3.04 \\
1.76 \\
1.68\end{array}$ & $\begin{array}{l}0.28 \\
0.27 \\
0.27\end{array}$ & $\begin{array}{l}0.13 \\
0.10 \\
0.09\end{array}$ & $\begin{array}{l}0.60 \\
0.20 \\
0.10\end{array}$ & $\begin{array}{c}- \\
0.60 \\
0.90\end{array}$ \\
\hline Site B & $\begin{array}{l}2.00 \\
1.68 \\
1.52\end{array}$ & $\begin{array}{l}3.28 \\
2.12 \\
1.44\end{array}$ & $\begin{array}{l}0.29 \\
0.08 \\
0.27\end{array}$ & $\begin{array}{l}0.10 \\
0.08 \\
0.07\end{array}$ & $\begin{array}{l}0.60 \\
0.40 \\
0.70\end{array}$ & $\begin{array}{l}3.30 \\
3.40 \\
3.30\end{array}$ \\
\hline Site C & $\begin{array}{l}1.44 \\
1.28 \\
0.98\end{array}$ & $\begin{array}{l}2.32 \\
2.16 \\
1.68\end{array}$ & $\begin{array}{l}0.30 \\
0.28 \\
0.28\end{array}$ & $\begin{array}{l}0.08 \\
0.07 \\
0.06\end{array}$ & $\begin{array}{l}0.80 \\
0.70 \\
0.80 \\
\end{array}$ & $\begin{array}{l}- \\
- \\
-\end{array}$ \\
\hline Site D & $\begin{array}{l}2.96 \\
1.84 \\
1.76\end{array}$ & $\begin{array}{l}1.20 \\
0.96 \\
0.80 \\
\end{array}$ & $\begin{array}{l}0.31 \\
0.29 \\
0.27 \\
\end{array}$ & $\begin{array}{l}0.23 \\
0.11 \\
0.08\end{array}$ & $\begin{array}{l}0.20 \\
0.30 \\
0.30 \\
\end{array}$ & $\begin{array}{l}- \\
- \\
-\end{array}$ \\
\hline Site E & $\begin{array}{l}4.16 \\
3.52 \\
2.88\end{array}$ & $\begin{array}{l}1.12 \\
0.48 \\
0.16\end{array}$ & $\begin{array}{l}0.29 \\
0.27 \\
0.26\end{array}$ & $\begin{array}{l}0.09 \\
0.07 \\
0.07\end{array}$ & $\begin{array}{l}0.20 \\
0.20 \\
0.80\end{array}$ & $\begin{array}{l}- \\
-\end{array}$ \\
\hline Site F & $\begin{array}{l}2.64 \\
2.00 \\
1.84\end{array}$ & $\begin{array}{l}1.52 \\
1.46 \\
0.40\end{array}$ & $\begin{array}{l}0.13 \\
0.29 \\
0.28 \\
\end{array}$ & $\begin{array}{l}0.09 \\
0.07 \\
0.07\end{array}$ & $\begin{array}{l}0.10 \\
0.30 \\
0.20\end{array}$ & $\begin{array}{c}1.30 \\
1.20 \\
0.8\end{array}$ \\
\hline Site G & $\begin{array}{l}1.92 \\
1.36 \\
1.04\end{array}$ & $\begin{array}{l}1.84 \\
1.04 \\
0.96\end{array}$ & $\begin{array}{l}0.32 \\
0.28 \\
0.27\end{array}$ & $\begin{array}{l}0.15 \\
0.07 \\
0.06\end{array}$ & $\begin{array}{l}0.30 \\
0.80 \\
0.30\end{array}$ & $\begin{array}{l}1.30 \\
1.00 \\
0.70\end{array}$ \\
\hline & 1.44 & 1.28 & 0.29 & 0.09 & 0.47 & 1.00 \\
\hline
\end{tabular}


Evaluation of Physicochemical Characteristics of Soils in the Flood Disaster Affected Areas of...

\begin{tabular}{|l|c|c|c|c|c|c|}
\hline Mean \pm SD & $\mathbf{1 . 9 7} \pm \mathbf{0 . 3 1}$ & $\mathbf{1 . 5 0} \pm \mathbf{0 . 2 7}$ & $\mathbf{0 . 2 8} \pm \mathbf{0 . 0 0 4 1}$ & $\mathbf{0 . 0 9} \pm \mathbf{0 . 0 1}$ & $\mathbf{0 . 4 3} \pm \mathbf{0 . 0 8}$ & $\mathbf{0 . 4 2} \pm \mathbf{1 . 0 2}$ \\
\hline Control Site & 5.28 & 0.64 & 0.30 & 0.17 & 0.20 & - \\
& 4.60 & 0.56 & 0.20 & 0.15 & 0.20 & - \\
& 3.36 & 0.48 & 0.28 & 0.09 & 0.30 & - \\
\hline Mean \pm SD & $\mathbf{4 . 4 1} \pm \mathbf{0 . 9 7}$ & $\mathbf{0 . 5 6} \pm \mathbf{0 . 0 8}$ & $\mathbf{0 . 2 6}$ & $\mathbf{0 . 1 4}$ & $\mathbf{0 . 2 3}$ & - \\
\hline
\end{tabular}

The exchangeable calcium and magnesium levels of the soils varied from $\left(\mathrm{mgkg}^{-1}\right) 0.98$ to 4.16 with mean value of $1.97 \pm 0.31$ and from 0.16 to 3.28 with mean value of $1.50 \pm 0.27$ respectively. The values obtained for calcium are almost in the same range with the values reported in a similar study [27] but lower than those documented in another study [4]. The exchangeable magnesium levels in this study are consistent with those reported elsewhere [4]. The low levels of these two elements may be associated with increased binding of calcium and magnesium ions to soil macrocolloid, thereby reducing availability of these ions in soil solution. The mobility of calcium and magnesium in soil is relatively restricted because of their higher ionic charge and thus are bound more to the exchangeable sites than ions of lower ionic charge. Exchangeable calcium and magnesium are secondary nutrients which are required in relatively smaller but in appreciable quantities [6]. Calcium deficiencies are rare when the soil $\mathrm{pH}$ is adequate [39]. Magnesium is a constituent of chlorophyll and chromosome [47].

Exchangeable sodium content varied from $\left(\mathrm{mgkg}^{-1}\right) 0.26$ to 0.32 with mean value of $0.28 \pm 0.004$. These values are in the same range with those reported elsewhere [27] but relatively lower than those reported in another related study [4]. The exchangeable sodium percentage (ESP) (Na 100/CEC), which expresses the relative contribution of sodium to overall exchange capacity is important to the problem of soil dispersion. An increase in exchangeable sodium percentage would bring about dispersion of the soil macrocolloid and a highly dispersed soil is characterized by defloccutation and crusting [49]. High levels of exchangeable sodium affect soil permeability and may be toxic to sensitive plants [50].

Exchangeable potassium levels varied from $\left(\mathrm{mgkg}^{-1}\right) 0.06$ to 0.23 with mean value of $0.09 \pm 0.01$. The values of exchangeable potassium obtained in this study are lower than the critical level of exchangeable potassium for most crops which was given as $0.20 \mathrm{mgkg}^{-1}$ [51]. Plants utilize potassium for photosynthesis (in the formation of carbohydrates) plant metabolism, regulation of enzyme activity and for increase of sugar, starch and oil content in plant storage organs [4]. Potassium in the soil may exist in unavailable, slowly available (exchangeable and available form in solution) and available form. The exchangeable form becomes available when the potassium in solution is removed by crops [52]

Exchangeable hydrogen levels varied from $\left(\mathrm{mgkg}^{-1}\right) 0.10$ to 0.80 with mean value of $0.43 \pm 0.08$. These low values may be due to depressed ionization of aluminum and hydroxyl and ferrous ions in solution [49].

Exchangeable aluminum was not detected in some of the sites. This may be attributed to increased binding of the ions to soil, macrocolloid at weakly acidic $\mathrm{pH}$. The values ranged from $\left(\mathrm{mgkg}^{-1}\right) 0.60$ to 3.40 with mean value of $0.42 \pm 1.02$. The presence of exchangeable aluminum at high saturation is closely related to soil infertility, as its ionization results in high soil acidity undesirable for arable crops $[4,53]$. At the level of $0.004 \mathrm{mgkg}^{-1}$, aluminum is toxic to many plants [49].

\section{Effective Cation Exchange Capacity (ECEC)}

The values of effective cation exchange capacity of the soil samples and other associated parameters are presented on table 3 .

Table 3: Effective Cation Exchange Capacities (ECEC) of the Soil Samples in all the Sites and other Associated

\begin{tabular}{|l|c|c|c|c|c|}
\hline Sample Site & Depth & ECEC & $\begin{array}{c}\text { Parameters } \\
\text { Base Exchange Capacity } \\
\left(\mathbf{C a}^{2+}+\mathbf{M g}^{\mathbf{2 +}}+\mathbf{N a}^{+}+\mathbf{K}^{+}\right)\end{array}$ & Base Saturation & Soil Buffering Capacity \\
\hline Site A & $0-15$ & 6.13 & 5.53 & 90.21 & 10.22 \\
& $15-30$ & 4.53 & 3.73 & 82.34 & 5.66 \\
& $30-45$ & 4.56 & 3.56 & 78.07 & 2.56 \\
\hline Site B & $0-15$ & 9.57 & 5.67 & 59.25 & 2.09 \\
& $15-30$ & 7.96 & 4.16 & 52.26 & 1.83 \\
\hline Site C & $30-45$ & 7.30 & 3.30 & 83.21 & 6.18 \\
& $0-15$ & 4.94 & 4.14 & 84.41 & 4.75 \\
\hline Site D & $15-30$ & 4.49 & 3.79 & 78.95 & 24.50 \\
& $30-45$ & 3.80 & 3.00 & 95.92 & 1.67 \\
& $0-15$ & 4.90 & 4.70 & 91.43 & 10.70 \\
\hline Site E & $15-30$ & 3.50 & 3.20 & 90.65 & 29.3 \\
\hline
\end{tabular}


Evaluation of Physicochemical Characteristics of Soils in the Flood Disaster Affected Areas of...

\begin{tabular}{|l|c|c|c|c|c|}
\hline & $15-30$ & 4.54 & 4.34 & 95.59 & 22.7 \\
& $30-45$ & 4.17 & 3.37 & 76.51 & 5.21 \\
\hline Site F & $0-15$ & 5.96 & 3.56 & 71.80 & 2.35 \\
& $15-30$ & 5.32 & 2.59 & 72.14 & 3.59 \\
& $30-45$ & 3.59 & 4.23 & 72.56 & 3.64 \\
Site G & $0-15$ & 5.83 & 2.75 & 60.44 & 2.53 \\
& $15-30$ & 4.55 & 2.33 & $\mathbf{7 7 . 5 7} \pm \mathbf{5 . 8 3}$ & $\mathbf{7 . 9 9 \pm 2 . 7 2}$ \\
\hline Mean \pm SD & $30-45$ & 3.33 & $\mathbf{3 . 8 7} \pm \mathbf{0 . 2 1}$ & 96.97 & 32.95 \\
\hline Control & & $\mathbf{5 . 0 7 6} \pm \mathbf{1 . 5 3 4}$ & 6.39 & 96.56 & 29.05 \\
& $0-15$ & 6.59 & 5.61 & 93.35 & $\mathbf{2 5 . 0 3}$ \\
\hline Mean \pm SD & $15-30$ & 5.81 & 4.21 & $\mathbf{9 5 . 6 3}$ & $\mathbf{2 5 . 6 8}$ \\
\hline
\end{tabular}

The effective cation exchange capacity $\left(\mathrm{Na}^{+}, \mathrm{K}^{+}, \mathrm{Ca}^{2+}, \mathrm{Mg}^{2+}, \mathrm{Al}^{3+}, \mathrm{H}^{+}\right)$is a $\mathrm{pH}$ dependent parameter of soils which expresses the degree of chemical activity of adsorption sites [54, 55]. The effective cation exchange capacity values obtained in the soils from all the sites ranged from $\left(\mathrm{mgkg}^{-1}\right) 3.21$ to 9.57 with mean value of 5.076 \pm 1.53 . Similar values have been reported [47]. These values decrease with soil depth in all the sites which is similar to the observation in the trend obtained in cases of Total Organic Carbon and Total Nitrogen contents in this study. This trend in effective cation exchange capacity values compared with the same trend in organic matter contents (TOC and $\mathrm{TN}$ ) corroborates the fact that soil organic matter has higher cation exchange values than all other soil constituents except vermiculite clays aluminium [23]. Surface and subsurface soil samples of the same soil can exhibit different capacities of heavy metal adsorption since the adsorption behaviour depends on the combination of soil properties (such as $\mathrm{pH}$ ) and the specific characteristics of the metal [56]. The decrease of cation exchange capacity with decrease in depth implies that the top or surface soils have greater capacity to adsorb metals. Most plant nutrients exist as cations and uptake of such nutrients is mainly controlled by $\mathrm{pH}$, cation exchange capacity and organic matter content of the soil.

Exchange capacity generally has higher levels of clay and organic matter. Cation exchange capacity is responsible for exchangeable cations such as $\mathrm{Ca}^{2+}, \mathrm{Mg}^{2+}, \mathrm{Na}^{+}$and $\mathrm{K}^{+}$which are readily available for plant uptake, and cations adsorbed to exchange, sites are more resistant to leaching or downward movement in soils with water [47].

\section{Base Exchange Capacity}

The base exchange capacity values $\left(\mathrm{Ca}^{2+}+\mathrm{Mg}^{2+}+\mathrm{Na}^{+}+\mathrm{K}^{+}\right)$varied from $\left(\mathrm{mgkg}^{-1}\right) 2.33$ to 5.67 with mean value of $3.87 \pm 0.21$ while the percentage base saturation $\left(\mathrm{Ca}^{2+}, \mathrm{Mg}^{2+}, \mathrm{Na}^{+}, \mathrm{K}^{+}\right)$100/ECEC values varied from 45.21 to 96.59 with mean value of $77.57 \pm 5.83 \%$. Similar values have been reported [4].

\section{Base Saturation}

The percentage base saturation expresses the relative contribution of the exchangeable bases to the overall exchange capacity and it is an important property of soil acidity useful for soil fertility evaluation because a high percentage base saturation implies desirable nutrient levels and low soil acidity. Since percentage base saturation means the amount of the cation exchange capacity not holding potential acidity, the mean value obtained in this study is consistent with the mean $\mathrm{pH}$ value observed.

\section{Soil Buffering Capacity}

The soil buffering capacity (SBC) $\left(\mathrm{Ca}^{2+}, \mathrm{Mg}^{2+}, \mathrm{Na}^{+}, \mathrm{K}^{+} / \mathrm{H}^{+}, \mathrm{Al}^{3+}\right)$ obtained is the ratio of exchangeable acidity. The soil buffering capacity values of the soil samples varied from 1.83 to 24.50 with mean value of $7.99 \pm$ 2.72. The values obtained in this study indicate a relatively low capacity of the soils to resist changes in $\mathrm{pH}$.

\section{Conclusion}

The present study revealed that the natural flood disaster affected the physicochemical properties of the soil to some extent. The flood led to decrease in soil $\mathrm{pH}$, phosphorus and nitrate as well as exchangeable calcium, potassium and effective cation exchange capacity (ECEC) and other associated parameters. It however, increased the exchangeable magnesium, sodium and exchangeable acidity (Hydrogen and Aluminum) while there was no appreciable change in Total Organic Carbon, Total Nitrogen and Sulphate contents. The overall implication of these results is that the flood increased the soil acidity, and decreased the capacity of the soil to adsorb metals but has no appreciable effects on contents of biodegradable and compostable materials. 
Evaluation of Physicochemical Characteristics of Soils in the Flood Disaster Affected Areas of...

Considering the overall after effects of the flood, it is thereby recommended that both State and Federal Governments should strongly discourage communities from settling within the flood plains. Buffer dams should be put in place to assist dams and the dredging of the Rivers Niger and Benue should be implemented without further delay.

\section{References}

[1]. Etuonovbe, A.K. The Devastating Effect of Flooding in Nigeria. TSO 6J - Hydrography and the Environment, Innocent Chirisa, Zimbabwe. FIG Working Week, 2011, P. 1-15.

[2]. Ojigi, M.L., Abdulkadir, F.I. and Adeyoju, M.O. Geospatial Mapping and Analysis of the 2012 Flood Disaster In Central Parts of Nigeria. 8th National G/S Symposium, Dammam, Saudi Arabia, April 15-17, 2013.

[3]. Rakesh, K., Rakesh, K.U., Kishan, S. and Brijesh, Y. Vertical Distribution of Physicochemical Properties under Different Topo Sequence in Soils of Jharkhand. Journal of Agricultural Physics, 2012 12(1) 63-69.

[4]. Egharevba, F., Olite, M. and Osakwe, S.A. Studies on the Effect of Laundry Effluent on the Physicochemical Properties of Soils in Edo State of Nigeria. Discovery and Innovation, 2003 15(1), 11-16.

[5]. Osakwe, S.A. Effect of Cassava Processing Mill Effluent on Physical and Chemical Properties of Soils in Abraka and Environs, Delta State, Nigeria. Chemistry and Material Research, 2012 2(7) 27-39.

[6]. Tukura, B.W., Yahaya, M. and Madu, P.C. Evaluation of Physicochemical Properties of Irrigated Soils. Journal of Natural Sciences Research. 2013 3(9), 135-139.

[7]. Ayodele, J.T. and Gaya, U.M. Chromium, Manganese and Zinc in Kano Municipality Street Dust. Journal of Chemical Society of Nigeria, 1998 23: 24-31.

[8]. Boulding, J.R. Description and Sampling of Contaminated Soils. 2nd Edition, Lewis Publishers, 1994 New York, No. AID.

[9]. Davey, B.J. and Conyers, M.K. Determining the pH of Acid Soils. Soil Science. 1988 146: 141-150.

[10]. Nelson, D.W. and Sommers, L.E. Total Carbon, Organic Carbon and Organic Matter. Methods of Soil Analysis, Part 2, 2nd Edition In: Page, A.Z. et al (Ed.) A.S.A., SSSA, Madison, W. 1982 539-571.

[11]. Bray, R.H. and Kurtz, L.T. Determination of Total Organic and Available Forms of Phosphorus in Soils. Soil Science, 1943 59: $39-45$.

[12]. Bouyoucos, G.J. Improved Hydrometer Method for Making Particle Size Analysis of Soils. Agronomy Journal. 1962 45: 464-465.

[13]. Schollenberger, G.J. and Simons, R.H. Determination of Exchangeable Capacity and Exchangeable Bases in Soils. Soil Science. 1945 59: $13-25$.

[14]. Jackson, J.E. and Burton, G.W. An Evaluation of Granite Meal as a Source of Potassium for Coastal Bermuda Grass. Agronomy Journal, 1958 50: 307-308.

[15]. ANON Analysis of Agricultural Materials. In: Ministry of Agriculture, Fishery and Food Reference Book 427, 1986 3rd Edition. HMSO London.

[16]. Chopra, G. and Kanzar, C. Analytical Agricultural Chemistry. 2nd Edition Prentice Hall, India. 1988

[17]. Onweremadu, E.U., Osiyi, G.E., Eshett, E.T., Okpara, C.C. and Ibeawuchi, I.I. Characterization of Owner Managed Farms of Abia and Imo States for Sustainable Crop Production in South-Eastern Nigeria. Journal of American Science 2007 3(1), 28-37.

[18]. Oguntimehin, I. and Ipinmoroti, K. Profile of Heavy Metals from Automobile Workshops in Akure, Nigeria. Journal of Environmental Science and Technology, 2007 1-8.

[19]. Okoye, G.O.B. and Agbo, K.E. Dispersion Pattern of Trace Metal in Soils Surrounding Solid Waste Dumpts in Nsukka. Journal of Chemical Society of Nigeria, 2011 36(2): 112-119.

[20]. Osakwe, S.A. Assessment of Wood Processing Industries in Selected Parts of Delta State, Nigeria, on the Soils and Vegetation in their Vicinities. 10SR Journal of Applied Chemistry, 2013 3(3): 22-30.

[21]. Mouvet, G. and Borg, A.C.M. Speciation including Adsorbed Species of Coppers, Lead, Nickel and Zinc on the Meuse Rivers. Water Research, 1983 6:641-649.

[22]. Iyenger, S.S., Martons, D.C. and Miller, W.P. Distribution and Plant Availability of Soil Zinc Fractions. Soil Science American Journal, 1981 45: 731-739.

[23]. Alloway, B.J. Bioavailability of Elements in Soil. Essentials of Medical Geology, Elsevier Inc. 2005 347-372.

[24]. Tripathi, A. and Misra, D.R. A Study of Physicochemical Properties and Heavy Metals in Contaminated Soils of Municipal Waste Dumpsites at Allahabad, India. International Journal of Environmental Sciences, 2012 2(4) 2024-2033.

[25]. Osenwoa, O.I. Effect of Abattoir Effluent on the Physical and Chemical Properties of Soils. Environmental Monitoring Assessment 1058-1064. 2009

[26]. Tukura, B.W., Kagbu, J.A. and Gimba, G.E. Effects of pH and Total Organic Carbon (TOC) on distribution of trace metals in Kubannic dam sediments, Zaria, Nigeria. Science World Journal 2007, 2(3):1-6.

[27]. Oviasogie., P. O. and Omornyi E. Levels of Heavy Metals and Physicochemical properties of soils in a foam manufacturing industry. Journal of Chemical Society of Nigeria. 32(1):102-106.2007.

[28]. Isirimah, N.O. and Dickson, A. Soil Chemistry. In: Introductory Soil Chemistry and Biology for Agriculture and Biotechnology. Isirimah, N.O. (Ed.), 19-32. 2003

[29]. Yun, O. Simulating Dynamic Load of Naturally Occuring Total Organic Carbon (TOC) from Watershed. Water Research. 2003 37:823832 .

[30]. Toboada, M.A. Soil Structural Behaviour of Flooded Soils. Lecture given at College of Soil Physics Trieste; 3rd - 21st March, 2003.

[31]. Morgan, P. and Watkinson, R.J. Hydrocarbon Degradation in Soils and Methods for Soil Biotreatment. CRC Critical Reviews. In Biolechnol. 1989 8(4): 305-330.

[32]. Peng, J., Song, Y., Yuan, P., Qui, X. and Qui, G. The Remediation of Heavy Metals Contaminated Sediment. Journal of Hazardous Materials, 2009 0161:633-640.

[33]. Rim-Rukeh, A. and Irerhievwie, G. Seasonal Variability of Nitrate Pollution In Drinking Water Resources in Niger Delta Area, Nigeria. Journal of Chemical Society of Nigeria. 2012 37: (2) 59-64.

[34]. Fogel, S., Findlay, M., Kerr, J. and McMillen, S. Incorporation of Petroleum Hydrocarbon into Soil Organic Matter during Biodegradation: Bioremediation Journal, 1998 3: 233-239. 
[35]. Eddy, N.O. Odoemelem, S.A. and Mbaba, A. Elemental Composition of Soil in Some Dumpsites Located within Ikot Ekpene, South Eastern Nigeria. Electronic Journal of Environmental Agricultural and Food Chemistry 2003 5: (3) 1002-1019).

[36]. Aluko, O.O., Sridha, M.K.C. and Oluwande, P.A. Characterization of Leachates from a Municipal Solid Waste Landfill Sites in Ibadan, Nigeria. Journal of Environmental Health Research. 20032 Issue 1.

[37]. Oviasogie P.O and Ofornaja, Available $\mathrm{Mn}, \mathrm{Zn}, \mathrm{Fe}, \mathrm{Pb}$ and Physicochemical changes associated with soil receiving cassava mill effluent. Journal of chemical Society of Nigeria, 2007 31(1)69-73.

[38]. Rai, S., Chopra, A.K., Chakresh, P., Dinesh, K., Renu, S. and Gupta, P.M. Comparative Study of some Physicochemical Parameters of Soil Irrigated with Sewage Water and Canal Water of Dehradun City, India. International Journal of Environmental Sciences, 2012 3(3), 318-325.

[39]. Snober, H.B., Afshana, B.D., Mohd, S.D. and Masood, M.G. Correlation of Soil Physicochemical Factors with Vam Fungi Distribution under different Agroecological Conditions. International Journal of Pharmaceutical and Biological Sciences. 2011 2(2), 99-106.

[40]. Bennett, W.F. Nutrient Deficiencies and Toxicities in Crop Plants APS Press, St. Paul, Minnesota, 1993

[41]. Udofia, P. A. Statistics for Social Scientists Calabar, PAF Publishers Inc. 2005 341-342,

[42]. Kristof, N. For Third World, Water is still a deadly drink, New York Times, Journal 1977 9: A1, A8: 13-15.

[43]. United Nations Commission for Sustainable Development. Comprehensive Assessment of the World. 1997 New York, 75-78.

[44]. Igwe, C.A. and Stahr, K. Waterstable Aggregates of Flooded Inceplicoils from South-Eastern Nigeria in Relation to Mineralogy and Chemical Properties Australian Journal of Soil Research, 2004 42: 171-179.

[45]. Ano, A.O., Odometam, S.A. and Ekwueme, P.O. Lead and Cadmium Levels on Soils and Cassava (Manihot Esculenta Grantz) along Enugu-Port Harcourt Expressway in Nigeria. Electronic Journal of Environmental Agriculture and Food Chemistry. 2007 6(5) 2024 2031.

[46]. Wilde, S.A., Weight, G.K. and Ixer, J.G. Soil and Plant Analysis for Tree Culture. Oxford B.H. Publication Company, New Delhi, p. 172. 1972

[47]. Mamun, S.A., Rahman, F., Yeasmin, F. and Islam, M.A. Suitability of the Physical Properties of Soil for Crop Production: A Study in Tangail Sadar. Journal of Environmental Science and Natural Resources, 2011 4(2): 121-125.

[48]. Isirimah, N.O., Dickson, A.A. and Igwe, C. Introductory Soil Chemistry and Biology for Agriculture and Biotechnology. Osia International Publishers Ltd., Port Harcourt. 2003

[49]. Foth, H.E. Fundamentals of Soil Science. John Wiley and Sons Inc. New York. 1984 Pp. 112-115.

[50]. McCauley, A., Jones, C. and Jacobsen, J. Soil and Water Basic Soil Properties. Management Module 1. 2005

[51]. Agboola, A.A. and Obighesan, O.O. The Response of Some Improved Crop Varieties to Fertilizers in Forest Zone of the Western Nigeria. Report of FAOIVVORAD/FED. Department, Agric Seminar on Fertilizers Use and Development in Nigeria, Lagos. P. 18. 1974

[52]. Ijaz, A., Farmanullah, K. and Bhatti, A.U. Some Physicochemical Properties of Soil as Influenced by Surface Erosion under different Cropping Systems on Upland-Sloping Soil. Soil and Environment, 2006 25(1) 28-34.

[53]. Evans, C.E. and Kamproth, E.J. Lime response at related to Percentage Aluminum Saturation and Organic Matter Content. Proceedings of Soil Science Society of America, 1970 34: 893-396.

[54]. Atuanya, E.I. Effect of Waste Engine Oil Pollution on Studies on the Effect of Laundry Effluent on the Physicochemical Properties of Soils in Edo State, Nigeria. Journal of Applied Science 1987 5(1), 155-176.

[55]. Egharevba, F., Osawe, E., Osemwota, I.O. and Oghboghodo, I.A. Effect of Detergent Solutions on Top Soils Physicochemical Properties in Edo State of Nigeria. Journal of Science, Engineering and Technology, 1999 7(1), 2292-2303. 